\title{
Banquo, A Paradox: A Conspirator and Murderer*
}

\author{
Lingmin Zhou \\ School of Liberal Arts \\ Jinan University \\ School of Foreign Studies \\ Southern Medical University \\ Guangzhou, China
}

\begin{abstract}
Macbeth by Shakespeare is rich in paradox not only in language styles but also in characterization. Banquo in Macbeth is a good example. Banquo fights with Macbeth against disloyal traitor and he helps Macbeth step by step to kill the king. At the same time, he has great influence on Macbeth's criminal psychology and it is he who to some degree leads to Macbeth's downfall, so Banquo is a paradox, a conspirator with Macbeth and a murderer of Macbeth.
\end{abstract}

\section{Keywords-Macbeth; Banquo; paradox}

\section{INTRODUCTION}

Tragedy itself is a paradox. It tries to create a perfect world and bring glory to human beings, but at the same time it brings pains to human beings, make people pity and suffer. The paradox reveals mystery of the world. Shakespeare's tragedies are extraordinary. Of his tragedies that are often called Shakespeare's "Big Four" (Hamlet, Othello, King Lear, Macbeth), Macbeth is the last, the shortest and the most concentrated in power [1]. Macbeth not only portraits great literal figures, as Macbeth, both a tyrant and murderer, Lady Macbeth, cruel and hard-natured, but also presents Shakespeare's great talent in rhetoric, especially the adaptation of paradox. Macbeth is rich in paradoxes that go deeper than the mere words [2], for instance, Macbeth's first sentence in the play "so four and fair a day I have not seen" [3] (I.iii. 39), and Witch's "Fair is foul, and foul is fair" (I.i. 10). The paradox is significant in the explanation of Macbeth's fate. Other paradoxes, as "Nothing is but what is not" and in the conversation between Lady Macduff and her son "Father'd he is, and yet he's fatherless" (IV.ii. 27), too pose some of the central riddles of life. In addition to mere paradox, the play also presents the paradoxical meaning in characters. The character behind Banquo is a good example. Banquo fights with Macbeth against disloyal traitor and he helps Macbeth step by step to kill the king. At the same time, he has great influence on Macbeth's criminal psychology and it is he who to some degree leads to Macbeth's downfall. So we say Banquo is a paradox, a conspirator with Macbeth and a murderer of Macbeth.

*This paper is sponsored by 2014 Annual Planning Project of Philosophy and Social Sciences in Guangdong(GD14CWW009) and 2013 Youth Cultivation Project of Guangdong College of Humanities and Social Science(2013WYM_0007).

\section{A CONSPIRATOR}

Many factors attribute to Macbeth's fate: Witches' prophecies, lady Macbeth's instigation, Macbeth's own swollen ambition and decisions. But many readers ignore another seeming minor but important character: Banquo. "Because the character behind Banquo in the play partakes in the battle against the character Duncun which places the character Macbeth on the throne, he is frequently thought of as either a silent conspirator with Macbeth and a false friend to Duncun" (Fendt, Gene). Banquo is a great helper in Macbeth's killing the king Duncun, despite the fact whether Banquo is conscious or unconscious of what he functions. $\mathrm{He}$ is a silent helper. Banquo first appears in Act I, scene3, after he and Macbeth defeat the enemy. On the way, they meet three Witches, who greet them "All Hail, Macbeth! Hail to thee, thane of Camdor" (49-50). "All Hail, Macbeth, that shalt be king hereafter" (51-52). Banquo reacts to their greetings "You greet with present grace and great prediction of noble having and of royal hope, which he seems rapt withal" (56-58). Banquo directly points out Witches' prophecies that strike on Macbeth's mind. Again, Banquo says, "you shall be king" (88). From then on, the idea of being king sows seeds in Macbeth's breast.

When Ross tells Macbeth he is called thane of Cawder, Banquo realizes that Witches' prophecy is proved. Hearing the news, Macbeth claims "Glamis, and thane of Cawdor. The greatest is behind" (I.iii. 118-119). Banquo does not share Macbeth's elation and he foreshadows what will happen on Macbeth: "Might yet enkindle you unto the crown, besides, the thane of Cawdor" (I.iii. 123-124), but he doesn't persuade Macbeth or give any constructive advice, and only speaks to Macbeth "Cousins, a word, I pray you" (I.iii. 128). At this moment Macbeth is ecstatic to be king, which paves the way for his later behaviors. Duncun sees his visit to Macbeth's castle as a strengthening of the bond between him and Macbeth. When he visits Macbeth's castle, Banquo says "The temple-haunting martlet, does approve by his lov'd mansionry that the heaven's breath smells wooingly here" (I.vi. 3-5). His words attract Duncun but are full of irony, implying the treacherous situation of Duncun. Banquo is a guard responsible for Duncun's safety. When Duncun is sleeping in Macbeth's castle, Banquo cannot sleep for "A heavy summons lies like lead upon me, and yet I would not sleep" (II.i. 7-8). Here, Banquo intuits what will happen but 
he doesn't take any measure to prevent the coming happening. Macbeth comes to Banquo and Banquo tells Macbeth "I dreamt last night of the three weird sisters. To you they have show'd some truth" (II.i. 20-21). Banquo's words again stir Macbeth's minds and strengthen his belief what Witches say are true and that he will be king. Also these words reinforce his decision of killing king and give him encouragement. In order to assure himself, and know what's in Banquo's mind, Macbeth continues saying, "If you shall cleave to my consent, when'tis, I shall make honor for you" (II.i. 25-27). Banquo replies "So I lose none, In seeking to augment it but still keep my bosom franchis'd and allegiance clear, I shall be counsel'd" (II.i. 26-29).

Banquo makes his position clear that he won't intervene with Macbeth's plan. We can see this point too in Act II, scene I, the very beginning is Banquo's soliloquy which implies he will say nothing and hide it. Therefore Macbeth is glade that all goes as what he expected. Nobody will be in the way of the realization of his great ambition. Then he can fulfill his plan without discovery. Now Macbeth is the king as Witches foretell. Macbeth runs through the roughest day successfully and Banquo plays a great role in his triumph.

\section{A MURDERER}

However a coin has two sides. The fact that Banquo pushes Macbeth on throne has both good and harm effect on Macbeth. After being king, Macbeth has chance to carry on further his fulfillment of his fate. Thus the more he realizes his dream, the nearer he meets his destined fate. If he had not been made king, he could not have reached his tragedy in the end. So in this respect Banquo's aid is disastrous. Banquo leads to Macbeth's destruction and he is rather a silent murderer of Macbeth. Banquo is the only person who knows Witches' prophecy. And Banquo's many conversation with Macbeth indicate that he has the intuition that Macbeth will do something improper to prove what Witches have said. "Restrain in me the cursed thoughts that nature give way to on repose" (II.i.9-10). Though Banquo is deadly tired, he restricts the summons to sleep. "I dream last night of the three weird sisters" (II.i. 20). All these show that Banquo guesses what Macbeth is up to. So to Macbeth, Banquo is a dangerous and critical person who can help him and also can destroy him. Banquo is a threat to Macbeth. Macbeth understands it quite well. After being king, Macbeth becomes more worried about Banquo:

\section{Our fears in Banquo}

Stick deep; and in his royalty of nature

Reigns that which would be fear'd: 'tis much he dares;

And, to that dauntless temper of his mind,

He hath a wisdom that doth guide his valour

To act in safety. There is none but he

Whose being I do fear: and, under him,

My Genius is rebuked; as, it is said,

Mark Antony's was by Caesar. He chid the sisters
When first they put the name of king upon me,

And bade them speak to him: then prophet - like

They hail 'd him father to a line of kings:

Upon my head they placed a fruitless crown,

And put a barren sceptre in my gripe,

Thence to be wrench'd with an unlineal hand,

No son of mine succeeding. If't be so,

For Banquo's issue have I filed my mind;

For them the gracious Duncan have I murder'd;

Put rancours in the vessel of my peace

Only for them; and mine eternal jewel

Given to the common enemy of man,

To make them kings, the seed of Banquo kings!

Rather than so, come fate into the list.

And champion me to the utterance. (III.i. 49-72).

So Macbeth makes his decision to kill Banquo. It seems that Macbeth fights against fate but in fact this fighting is just his fate. Macbeth carefully plans to kill Banquo, but three murderers let the son, Fleance escape. Again fate plays a joke on Macbeth. Macbeth is "cabin'd, cribb'd, confin'd, bound in. To saucy doubts and fears" (III.iv. 24-25). Fleance's escape is the exact climax of Macbeth. It is unquestionably an event of momentous significance, for Macbeth "has lost best half of his affair" (III.iv. 20-21) His learning of Fleance's escape is the turning point of Macbeth. Macbeth knows Witches' prophecy is spelling on him. His attempt to thwart Fate by hiring the murderers to kill Banquo and Fleance fails. Ironically, he defeats his own purpose. He had planned to pluck Banquo's influence away, but eventually is doomed to lose it. Now, he is occupied by the thought: "There the grown serpent lies; the worm that's fled. Has nature that in time will venom breed, No teeth for the present" (III.iv. 28-31). So Banquo's image is haunting in Macbeth's mind and causes his psychological damage.

Furthermore, the effect of Banquo's ghost is powerful. In Macbeth, Shakespeare employs supernatural writing method. Banquo's ghost appears several times, which disturbs Macbeth very much. In the end of the play, Macbeth is overcome by Banquo's ghost:

Approach thou like the rugged Russian bear

The arm'd rhinoceros, or the Hyrcan tiger;

Take any shape but that, and my firm nerves

Shall never tremble: or be alive again,

And dare me to the desert with thy sword;

If trembling I inhabit then, protest me 106)

The baby of a girl. Hence, horrible shadow! (III.iv. 100- 
Tired of moving things in a direction contrary to what fate intends, Macbeth surrenders to Fate and goes to consult Witches. He shows confidence in them. Witches tell him that "beware of Macduff" (IV.i. 71). "He will not be commanded. Here's another more potent than the first" (IV.i. 75-76)." The power of man, for none of woman born shall harm Macbeth" (IV.i. 80-81) and "Macbeth shall never vanquish'd be until Great Birnam wood to high Dunsinane hill shall come against him" (IV.i. 91-94).Macbeth doesn't believe Great Birnam wood would rise but he is only fretted about Banquo: "Yet my heart throbs to know one thing. Tell me, if your art can tell so much, shall Banquo's issue ever Reign in this kingdom" (IV.i. 100-102). When Witches tell him "seek to know no more" (IV.i. 103), Macbeth sticks to it "and an eternal curse fall on you. Let me know" (IV.i. 105). Banquo's image blinds Macbeth to be alert to other dangerous person. He only concerns himself with Banquo. When Witches vanish, eight kings appear and "the last with a glass in his hand, Banquo's Ghost following" (IV.i. 102). Banquo's Ghost again bothers Macbeth: "Thou art too like the spirit of Banquo. Thy crown does sear mine eyeballs" (IV.i. 112-113). "Horrible sight! Now I see 'tis true. For the blood-bolter'd Banquo smiles upon me, and points at them for his" (IV.i. 122-124). Banquo's image pushes Macbeth further his struggle with fate. From then on, Macbeth becomes more tyrannous and heartless. "I have almost forgot the taste of fears. The time has been, my senses would have cool'd" (V.v. 9-14). He kills Macduff's wife and son, later meets Macduff's forces and is murdered by Macduff, who "was from his mother's womb untimely ripp'd."(V.viii. 15160). The harder Macbeth's heart become, the more disastrous his end is. To some extent, it is Banquo who moulds Macbeth's character and makes Macbeth nearer and nearer to be a real murderer. Behind Macbeth, Banquo is an imaginary knife that ends Macbeth's life.

\section{CONCLUSION}

In the play, the character of Macbeth is main clue, and Banquo is underlying clue threading through the whole play, controlling the character's development. Banquo aids Macbeth to be king, so he is a friend to Macbeth and an enemy to Duncun. He silently kills Macbeth, so he is too a false friend and a murderer to Macbeth. Thus Banquo is a paradox in the play. The characterization of Banquo reveals the complex of human being's living condition and the deep contradiction of human nature. It causes human beings to "identify themselves" and to question themselves "who am I?"

\section{REFERENCES}

[1] Fan Zhong Sheng. "Brief Analysis of Banquo's Image and Macbeth by Contrast”. Journal of Xi'an United University, Jan 2004

[2] Fendt,Gene. "Banquo: A false Faux Ami?" Note \&Quries. Jun 2005. EBSCO Database

[3] Shakespeare. Macbeth. The English Tradition: Drama. New York: Macmillan Publishing Company, 1984.

[4] Xie Jingqiu, "On Tragedy and Forms”, Foreign Literature 6 (2005) 23-28. 